\title{
Production of Free Radicals and Oxygen Consumption by Primary Equine Endothelial Cells During Anoxia-Reoxygenation
}

\author{
Geoffroy de la Rebière de Pouyade ${ }^{* 1,2}$, Alexandra Salciccia ${ }^{1,2}$, Justine Ceusters ${ }^{2}$, \\ Ginette Deby-Dupont ${ }^{2}$, Didier Serteyn ${ }^{1,2}$ and Ange Mouithys-Mickalad*,2
}

\author{
${ }^{I}$ Department of Clinical Sciences, Equine Clinic, Faculty of Veterinary Medicine B41, University of Liège, Sart Tilman, \\ 4000 Liège, Belgium \\ ${ }^{2}$ Center for Oxygen Research and Development, Institute of Chemistry B6a, University of Liège, Sart Tilman, 4000 \\ Liège, Belgium
}

\begin{abstract}
The endothelium plays an active role in ischemia/reperfusion injuries. Herein, we report the effect of a single or successive cycles of anoxia/reoxygenation $(\mathrm{A} / \mathrm{R})$ on the mitochondrial respiratory function of equine endothelial cells (cultured from carotids) monitored by high resolution oxymetry, and on their production of reactive oxygen species (ROS). ROS were measured by electron paramagnetic resonance (ESR) using POBN and DMPO spin traps, and by gas chromatography (GC) of ethylene released by ROS-induced $\alpha$-keto- $\gamma$-(methylthio)butyric acid (KMB) oxidation. The oxygen consumption significantly decreased with the number of A/R cycles, and POBN-ESR spectra were specific of adducts formed in the cells from superoxide anion. After a one-hour A/R cycle, high intensity DMPO-ESR spectra were observed and assigned to superoxide anion trapping; the GC results confirmed an important production of ROS compared to normoxic cells. These results show that $\mathrm{A} / \mathrm{R}$ induces mitochondrial alterations in endothelial cells, and strongly stimulates their oxidative activity as demonstrated by ESR and GC methods.
\end{abstract}

Keywords: Equine endothelial cell, Anoxia/Re-oxygenation, High-resolution Oxygraphy, Gas Chromatography, Electron Spin Resonance, Reactive Oxygen Species, Free radicals.

\section{INTRODUCTION}

Ischemia-reperfusion injury still remains a leading cause of organ failure both in human and horses that is associated to high morbidity and mortality. The endothelial cell monolayer is a critical interface between blood and tissues and a selective permeable barrier. In healthy conditions, endothelial cells regulate the blood flow by acting on smooth muscle cells, maintain an antithrombotic surface, participate to the coagulation system, and synthesize various autocrine and paracrine growth factors active in neoangiogenesis and wound healing. Endothelial cells also actively participate to inflammatory disorders, notably by modulating the extravasations of leucocytes through the up-regulation of adhesion molecules [1-3]. By interacting with neutrophils and modulating vascular tone, endothelium plays a role in ischemia-re-oxygenation $(\mathrm{I} / \mathrm{R})$ injuries and contributes to the multiple organ dysfunctions occurring after sepsis or endotoxemia [3-5].

$\mathrm{I} / \mathrm{R}$ injuries are strongly associated with a recruitment and activation of leucocytes, mainly polymorphonuclear neutrophils $[4,6]$, which induce endothelial dysfunction and participate in ischemia/reperfusion (I/R)-induced tissue damages by releasing proteases and producing reactive

*Address correspondence to these authors at the Center for Oxygen Research and Development, Institute of Chemistry B6a, University of Liège, Sart Tilman, 4000 Liège, Belgium; Tel: +32 4-366-33-66; Fax: +32 4-36628-66; E-mails: G.delaRebieredePouyade@ulg.ac.be; amouithys@ulg.ac.be oxygen species (ROS), notably through the NADPH-oxidase/ myeloperoxidase (MPO) system [7-11]. The neutrophils are considered as the main source of oxygen radicals during myocardial I/R [12].

On the other hand, it has been reported that endothelial cells are also able to produce ROS during hyperoxic or hypoxic events as demonstrated by in vitro studies using electron spin resonance (ESR)-spin trapping methodology, a powerful tool to evidence a free radical production $[13,14]$. This ROS production was first attributed to the activity of xanthine oxidase formed from xanthine dehydrogenase during anoxia. However, in the literature data other sources of reactive oxygen and/or nitrogen species are described: for instance NO synthase and NADPH oxidase are considered as important sources of ROS in endothelial cells [15]. Moreover, a growing interest is devoted to mitochondria as one of the main intracellular sources of ROS in normal and pathological conditions. Mitochondria from various tissues can be both the generator and the trigger of ROS [16], especially in I/R conditions.

Currently, I/R or ischemia / no reflow phenomenon injuries are involved as primary or secondary events in many human diseases [17-20]. In horse, colic with strangulated intestinal disorders and laminitis are 2 major pathologies leading to euthanasia, and suspected to be associated with $\mathrm{I} / \mathrm{R}$ tissue injuries $[21,22]$. However, there are no data showing a clear evidence of free radicals and ROS production by equine endothelial cells when submitted to anoxia-reoxygenation $(A / R)$. Herein, we report the effect of 
$\mathrm{A} / \mathrm{R}$ applied to equine endothelial cells in culture as a model to establish a relationship between the rate of oxygen consumption (cell respiration) monitored by high-resolution oxygraphy and the free radicals production evidenced by ESR-spin trapping spectroscopy and indirectly by Gas Chromatography (GC) analysis of ethylene generated from the attack of a substrate (KMB) by ROS.

\section{MATERIALS AND METHODOLOGY}

\section{Reagents}

Trypan blue was from Merck (Darmstadt, Germany). Collagenase, type A gelatine from porcine skin, antibiotics, amphotericin B, anti-von Willebrand factor and endothelin-1 antibodies, $\alpha$-keto- $\gamma$-(methylthio)butyric acid (KMB), sodium dithionite $\left(\mathrm{Na}_{2} \mathrm{~S}_{2} \mathrm{O}_{4}\right)$, and $\alpha$-(4-pyridyl 1-oxide)- $\mathrm{N}$ tert-butylnitrone (POBN) were purchased from SigmaAldrich (Steinheim, Germany). Dulbecco's Modified Eagle Media (DMEM), Hank's Balanced Salt Solution (HBSS), Trypsin/EDTA (0.05/0.02\%), Fetal Bovine Serum (FBS) and Horse serum were from Gibco, Invitrogen (Merelbeke, Belgium). Endothelial cell growth factor (ECGF) and Horse radish peroxidase (HRP) were from Roche (Mannheim, Germany). Culture plates and dishes were purchased from Nunc A/S (Roskilde, Denmark). Falcon tubes were from BD Biosciences (Erembodegem, Belgium). 5,5'-dimethyl-1pyrroline-N-oxide (DMPO) was obtained from Alexis Biochemicals (Lausen, Switzerland).

\section{Endothelial Cells Culture}

Carotid arteries of horses were harvested after the euthanasia of the animal for humanitarian reason, put in sterile HBSS and treated within 1 hour as previously described [23]. Briefly, the vessels were dried and rinsed several times with $\mathrm{HBSS}$ at $37^{\circ} \mathrm{C}$ to eliminate residual blood clots. The ends of the vessels were closed and a solution of $0.1 \%$ collagenase in HBSS was injected in the lumen. After a 10 -minute period of incubation at $37^{\circ} \mathrm{C}$ to achieve enzymatic digestion, the liquid was collected in a falcon tube containing a solution of $25 \%$ FBS in HBSS. The vessels were rinsed several times with the same solution. Vessels were then longitudinally opened and the intima was delicately scraped with a plastic spatula in a second tube. The Falcon tubes were centrifuged for $10 \mathrm{~min}$ at $200 \mathrm{~g}$, the pellets suspended in fresh culture medium and put in culture in $9.6 \mathrm{~cm}^{2}$ dishes coated with a solution of $0.2 \%$ gelatine. The culture medium was DMEM with pyruvate, Lglutamine, $5.55 \mathrm{mM}$ glucose, 10\% FBS, 5\% equine serum, penicilline $[100 \mathrm{IU} / \mathrm{ml}]$, streptomycine $[100 \mu \mathrm{g} / \mathrm{ml}]$, gentamycin $[100 \mu \mathrm{g} / \mathrm{ml}]$, amphotericine B [1.25 $\mu \mathrm{g} / \mathrm{ml}]$, ECGF $[20 \mu \mathrm{g} / \mathrm{ml}]$. Cells were characterized by phenotypical aspect and immunofluorescence detection of the von Willebrand factor and the endothelin-1. Confluent endothelial cells were detached with a Trypsin / EDTA $(0.05 \% / 0.02 \%)$ solution before their spreading for further growth ("passage"). Cells at passages 5 to 7 were used in A/R experiments.

\section{Oxygraphy and Anoxia/Reoxygenation}

\section{Multiple Cyclic A/R}

The kinetics of $\mathrm{O}_{2}$ consumption of primary equine endothelial cells was recorded by oxygraphy (Oroboros oxygraph, Paar Physica, Austria) with a Clark electrode, at $37^{\circ} \mathrm{C}$. The oxygraph was calibrated by addition of dithionite to air saturated buffer to establish the zero level of $\mathrm{O}_{2}$ concentration. The cells $\left(10^{7}\right.$ by assay) were suspended in 2 $\mathrm{ml}$ of HBSS-glucose and transferred into the respiratory chamber of the oxygraph. The measurement was performed under continuous stirring and started just after the closing of the chamber. Anoxia started after complete consumption of the $\mathrm{O}_{2}$ dissolved in the medium (zero $\mathrm{nmol} \mathrm{O}_{2} / \mathrm{ml}$ ) and was maintained for 20 minutes. Reoxygenation was performed by opening the chamber and exposure of the stirred medium to air until $\mathrm{O}_{2}$ saturation (return to the pre-anoxia level of $\mathrm{O}_{2}$ concentration). Afterwards, the respiration chamber was closed again, the respiration rate monitored and a new cycle of $A / R$ performed. Three cycles of $A / R$ were achieved (Fig. 1A). As control, $10^{7}$ cells were suspended in $2 \mathrm{ml}$ HBSSglucose buffer, transferred into the second chamber (control chamber) without complete closing and maintained under stirring until the end of the experiment. The slopes of $\mathrm{O}_{2}$ consumption were calculated with the Oroboros oxygraph software and transformed into relative values by taking the initial slope (slope 1, Fig. 1A) as reference value (100\%). The cellular viability was measured by trypan blue exclusion assay before and after each measurement. The experiment was repeated 10 times with new cell batches obtained from 3 horses. For ESR measurements, A/R cycles were performed in the presence of the mixture of POBN and ethanol (see Free radicals detection).

\section{Single A/R Sequence}

A 1-hour period of anoxia / re-oxygenation was performed as described above, but with $10^{7}$ cells suspended in $10 \mathrm{mM}$ phosphate buffer saline (PBS) containing $137 \mathrm{mM}$ $\mathrm{NaCl}$ and $2.7 \mathrm{mM} \mathrm{KCl}$ (pH 7.4). During re-oxygenation, the cell suspension was either added with the spin trap DMPO for ESR analyses or transferred into vials for gas chromatography analysis to monitor the ROS production (see Free radicals detection).

\section{Free Radicals Detection and ROS Measurement}

\section{ESR Spin Trapping Investigation of Free Radicals Produced by Primary Equine Endothelial Cells}

Two types of A/R experiments with endothelial cells were designed by coupling oxygraphy and ESR. After 3 cycles of $\mathrm{A} / \mathrm{R}$ in the presence of $50 \mathrm{mM}$ POBN/2\% ethanol mixture or after a single period of anoxia followed by the addition of $100 \mathrm{mM}$ DMPO just before re-oxygenation, the cell suspension was transferred in each case into the ESR quartz flat cell, which was put into the cavity of the ESR spectrometer. The generation of free radicals by endothelial cells submitted to $\mathrm{A} / \mathrm{R}$ was evaluated by monitoring the appearance of ESR spectra, characteristic of POBN/ethoxy and DMPO-OH or DMPO-OOH radical spin adducts. The measurements were carried out at room temperature with a Bruker spectrometer (Bruker, Karlsruhe, Germany), operating at X-band frequency $(9.8 \mathrm{GHz})$ and at a microwave power of $20 \mathrm{~mW}$. The instrumental settings were the following: $100 \mathrm{KHz}$ modulation frequency, $1.012 \mathrm{G}$ modulation amplitude, $3480 \mathrm{G}$ magnetic field centre, and receiver gain was $2.10^{4}$. The sweep width was $100 \mathrm{G}$ and the total number of scans was 6 . The hyperfine splitting constants were measured from the experimental spectra by 
means of a Bruker Win-Simfonia program running under Microsoft Windows. The assays were repeated three times for both cyclic and single period of $A / R$.

\section{Gas Chromatography Analysis of ROS Production by Equine Endothelial Cells}

The GC analysis allows to detect the production of ethylene as a by-product resulting from the attack by ROS produced by endothelial cells on the substrate $\alpha$-keto- $\gamma$ (methylthio)butyric acid (KMB). After $1 \mathrm{~h}$ of anoxia (see above), endothelial cells were re-oxygenated and split in 2 vials of $10 \mathrm{ml}\left(5.10^{6}\right.$ cells in $1 \mathrm{ml}$ per vial $)$ KMB and HRP dissolved in PBS were added to reach a final concentration of $170 \mu \mathrm{g} / \mathrm{ml}$ and $45 \mu \mathrm{g} / \mathrm{ml}$ respectively. Afterwards, the vials were immediately closed with rubber stoppers and sealed. The mixture was incubated at $37^{\circ} \mathrm{C}$ for $1 \mathrm{~h}$ to allow

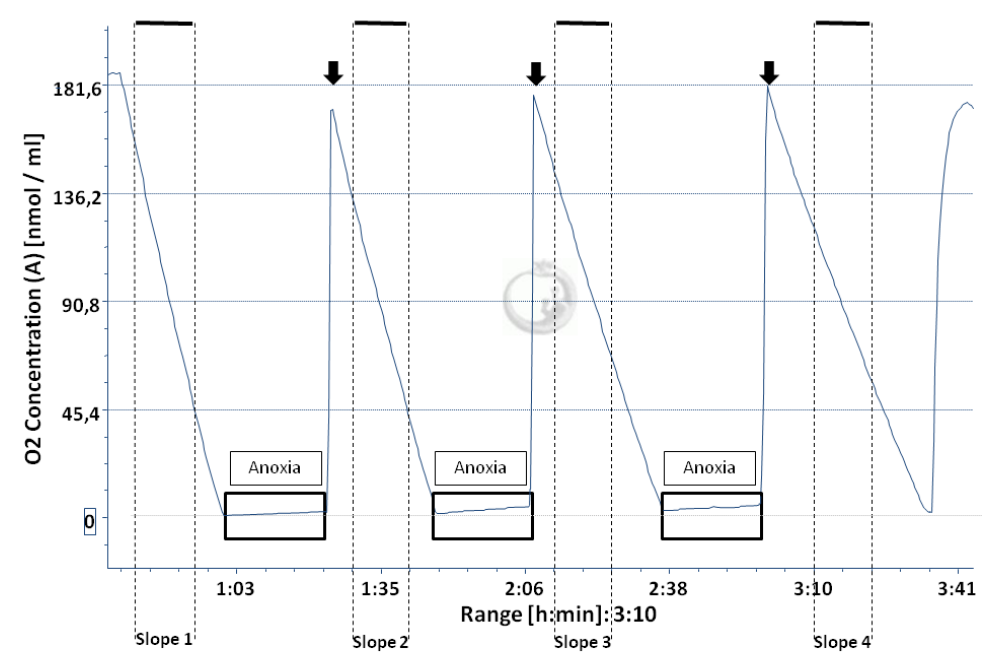

A

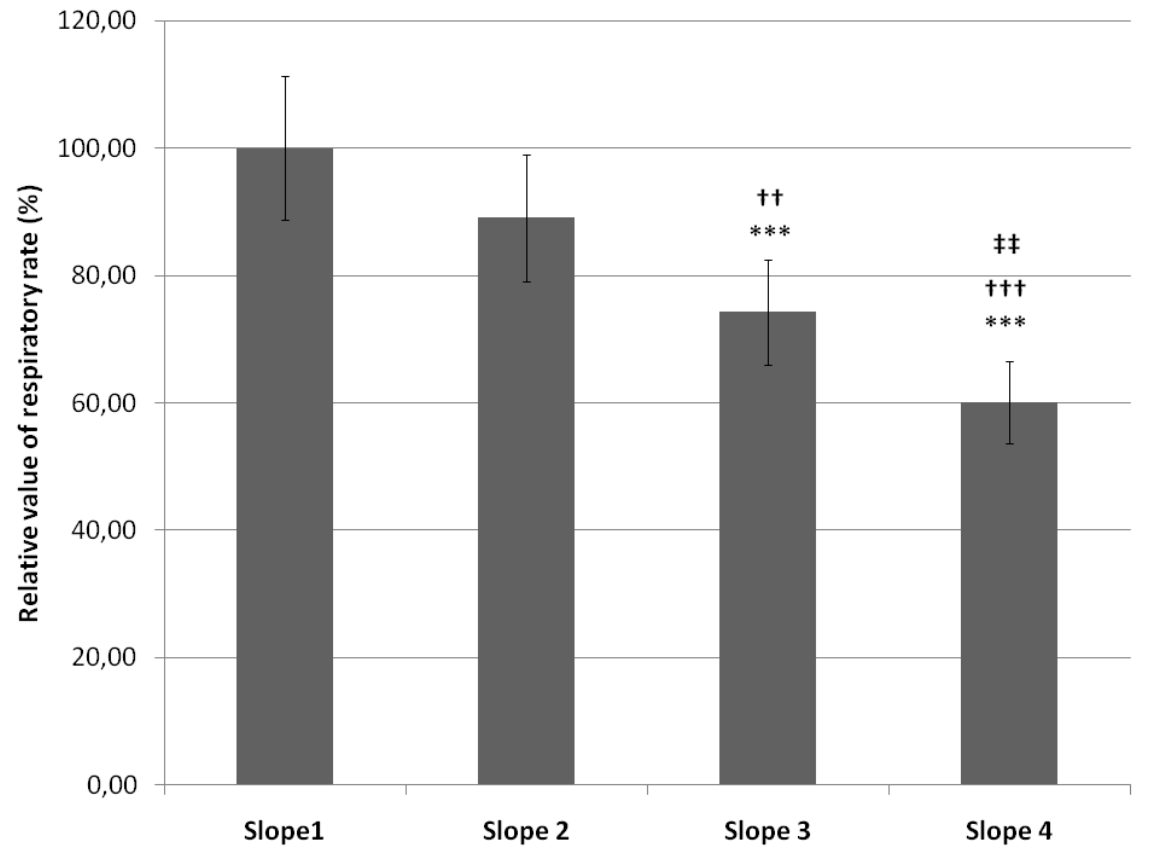

B

Fig. (1). A: Typical example of a complete protocol of three anoxia / reoxygenation cycles of equine endothelial $\left(10^{7}\right)$ cells monitored by oxygraphy. The black boxes represent the periods of anoxia and the arrows indicate the re-oxygenation steps.

B: Decrease of the relative value (mean $\pm \mathrm{SD} ; \mathrm{n}=10$ ) of the respiratory rate measured on cultured endothelial $\left(10^{7}\right)$ cells after each cycle of anoxia/reoxygenation (slopes 2, 3 and 4). The mean value measured for the slope 1 (before anoxia) was taken as $100 \%$ ( $\mathrm{n}=10$ ).

$* * * P<0.001$ versus the slope 1 .

$\dagger \dagger P<0.01$ and $\dagger \dagger \dagger P<0.001$ versus the slope 2 .

$\$ \ddagger P<0.01$ versus slope 3 . 
the oxidation of the KMB substrate by the radical species produced by cells, resulting in ethylene release, which accumulated in the gaseous phase [24]. At the end of the incubation period, the level of KMB oxidation was estimated by quantifying the ethylene amount (nmoles) by gas chromatography on a Porapak T column ( $1 \mathrm{~m}$ length; ID 1/8 inch; supplied by Supelco, Belgium) at $80^{\circ} \mathrm{C}$. Nitrogen was used as carrier gas $(40 \mathrm{ml} / \mathrm{min})$. Flame ionization detector and injector temperatures were both set at $120^{\circ} \mathrm{C}$. The experiment was repeated three times in duplicate.

\section{Statistical Analyses}

Statistical treatments were performed by using Instat (version 3.05) program. Indicated values are means \pm Standard Deviation (SD). Differences between the respiratory slopes were tested by using a one-way anova with Tukey's post test. The variation of ethylene release measured by GC was assessed by an unpaired $t$ test with Welch correction. The significance was set at $P<0.05$.

\section{RESULTS}

\section{Effects of $\mathrm{A} / \mathrm{R}$ Cycles on $\mathrm{O}_{2}$ Consumption of Equine Endothelial Cells}

Fig. (1A) shows that after 3 cycles of anoxia/reoxygenation the respiratory ability of endothelial cells was reduced as illustrated by a progressive slow down of their $\mathrm{O}_{2}$ consumption. In comparison with the slope 1 , taken as control (slope value $=100 \%$ ), slopes 2, 3 and 4 decreased by $10.95,25.76$, and $39.94 \%$, respectively. The first decrease (slope 2) was not statistically significant while the decrease of slope 3 and 4 was significant compared to slope 1 (Fig. 1B). Slopes 3 and 4 were significantly decreased compared to slope 2, and there was also a significant difference between the slopes 3 and 4 . The cell mortality between the onset and the end of the experimental protocol was respectively $6.13 \pm 2.39$ and $10.11 \pm 4.07 \%$ for control and $\mathrm{A} / \mathrm{R}$ groups and was not significant.

\section{ESR-Spin Trapping Study on the Effect of A/R Cycles on Free-Radicals Production by Endothelial Cells}

Fig. (2) shows the ESR spectra obtained from the reaction of free radicals produced by primary equine endothelial cells in the presence of the POBN/ethanol mixture. After A/R sequences applied to $10^{7}$ cells in HBSS supplemented with POBN (50 mM)/ethanol (2\%, v/v) mixture, a high ESR spectrum was observed (Fig. 2B) in comparison with cells maintained in normoxia (Fig. 2A). The triplet of doublets ESR spectrum (Fig. 2B) can be assigned to the $\mathrm{POBN} /{ }^{\bullet} \mathrm{CH}(\mathrm{OH}) \mathrm{CH}_{3}$ adducts which result from the reaction of POBN with ethoxy radicals that originated from the attack of free radicals. The following experimental splitting was obtained: $a(\mathrm{~N})=16.2 \mathrm{G}$ and a $(\mathrm{H})=2.6 \mathrm{G}$.

\section{Effect of a Single Period of Anoxia/ Reoxygenation on ROS Production}

\section{ESR Analysis}

To assess the effect of a single period of anoxia on the production of ROS by endothelial cells, another spin trap was used to evidence the formation of ROS. Therefore, DMPO was added after anoxia sequence and just prior reoxygenation of the cellular suspension. Fig. (3) shows that after $1 \mathrm{~h}$ of anoxia followed by reoxygenation in the presence of $100 \mathrm{mM}$ DMPO, an enhanced production of free radicals was observed when compared with cells remained in normoxia. The four-line EPR spectrum was characteristic of
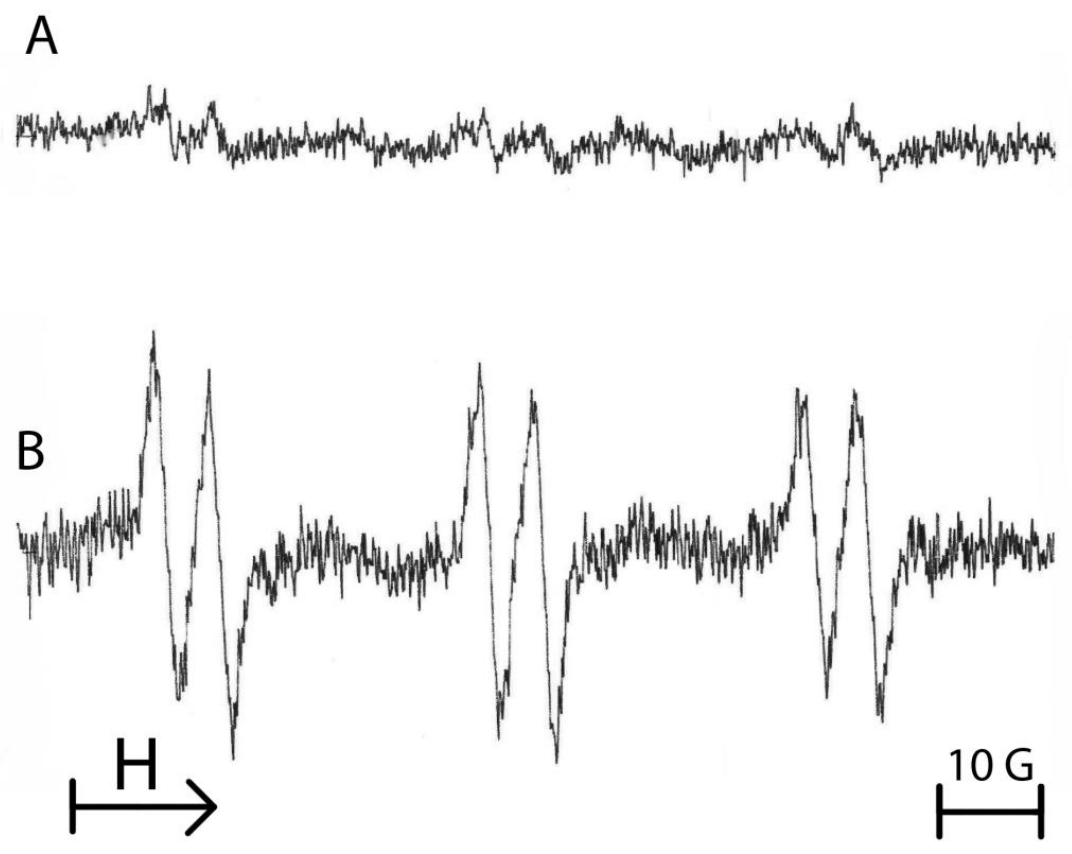

Fig. (2). Typical example of the ESR spectra obtained from $10^{7}$ equine endothelial cells submitted either to normoxia (A) or to 3 cycles of anoxia/reoxygenation in the presence of the spin trap $50 \mathrm{mM}$ POBN/2\% ethanol (B). The spectrum B shows a triplet of doublets, characteristic of a POBN adduct with an ethoxy radical. Results from 3 separate experiments. 


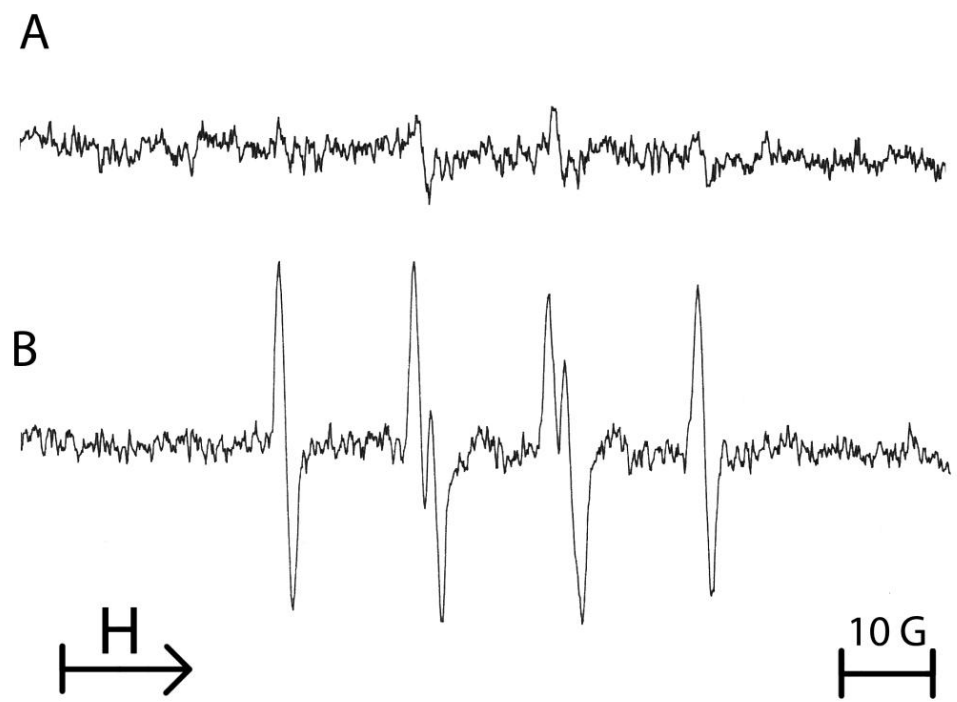

Fig. (3). Typical example of the ESR spectra obtained from $10^{7}$ equine endothelial cells submitted either to normoxia (A) or to a single 1 hour-period of anoxia/reoxygenation with addition of $100 \mathrm{mM} \mathrm{DMPO}$ at the time of reoxygenation (B). The spectrum B is characteristic of the reaction of DMPO with superoxide anion. Results from 3 separate experiments.

both DMPO-OOH and DMPO-OH adducts, resulting from the trapping of superoxide anion by the spin trap agent DMPO (Fig. 3). The hyperfine coupling constants were: i) a $(\mathrm{N})=14.5 \mathrm{G},\left(\mathrm{a}_{\mathrm{H}}\right)^{\alpha}=11.3 \mathrm{G},\left(\mathrm{a}_{\mathrm{H}}\right)^{\beta}=1.3 \mathrm{G}$ for DMPO-OOH and ii) a $(\mathrm{N})=\mathrm{a}(\mathrm{H})=14.9 \mathrm{G}$ for DMPO-OH.

\section{Gas Chromatography Analysis}

In parallel to ESR and $\mathrm{O}_{2}$ consumption measurements, the ROS production from endothelial cells was evidenced based on the ethylene release. After $1 \mathrm{~h}$ of anoxia followed by reoxygenation, a significant increased production of ethylene was observed, indicator of the ability of the cells to oxidize KMB. The production of ethylene by the cells submitted to anoxia was $804 \%$ compared to control cells taken as $100 \%$ (Fig. 4).

\section{DISCUSSION}

Ischemia/reperfusion injury is one of the major causes of cell death. The prolonged oxygen deprivation within the tissue, which is characterized by the ATP depletion of the cells, results in swelling of mitochondria with subsequent release of cytochrome $\mathrm{c}$. The latter one activates an apoptotic signaling cascade, i.e. caspases, and participates to the inflammatory response $[25,26]$. These findings make mitochondria as a major source of ROS at the intracellular level, even though other sources can contribute to harmful effects of reactive oxygen species. Several experimental in vitro and in vivo models have been designed to understand the mechanisms underlining I/R injuries [27-29].

Herein, we report from a primary culture of equine endothelial cells a model of anoxia-reoxygenation to monitor the production of ROS and to establish a relationship with cellular oxygen consumption, by coupling high resolution oxygraphy with ESR-spin trapping technique and GC analysis. We demonstrated that the oxygen consumption by equine endothelial cells, accurately followed by high sensitive oxygraphy, was affected by $A / R$ with a subsequent production of free radicals in comparison with cells simultaneously maintained in normoxia. A tight relation was established between this cellular respiration dysfunction of endothelial cells caused by A/R sequence and the free radical production monitored by both ESR and GC techniques.

Indeed, multiple cycles of $\mathrm{A} / \mathrm{R}$ induced an oxygen consumption reduction that increased after each anoxia/reoxygenation period. By choosing to apply three periods of 20 minutes anoxia, we thought that the cell mortality would be low [29]. Indeed, at the end of the experimental protocol, we observed a slight loss of cell viability that could not explain, at least totally, the slowing of the $\mathrm{O}_{2}$ consumption, which can thus be attributed to an alteration of the mitochondrial respiratory mechanisms.

By ESR spin trapping methodology, we have found that after three A/R cycles, the resulting ESR spectrum was characteristic of the POBN/ethoxy adducts. These latter ones result from the reaction of the superoxide anion by-product, i.e. hydroxyl radical $(\cdot \mathrm{OH})$, with ethanol, leading to ethoxy radical which is then trapped by POBN. Similar findings have been previously reported in $\mathrm{A} / \mathrm{R}$ model on isolated liver mitochondria [30].

Additional to POBN, which allowed us to monitor the free radicals generation during successive A/R cycles, another spin trap agent (DMPO) was used for a single 1 hour $\mathrm{A} / \mathrm{R}$ experiment, and demonstrated that equine endothelial cells submitted to a long period of anoxia, produced a high intensity ESR spectrum which was assigned to the trapping of superoxide anion $\left(\mathrm{O}_{2}^{-}\right)$.

The results obtained by coupling the measurement of $\mathrm{O}_{2}$ consumption (oxygraphy) and ESR data were confirmed by an indirect method to detect ROS: the GC measurement of 


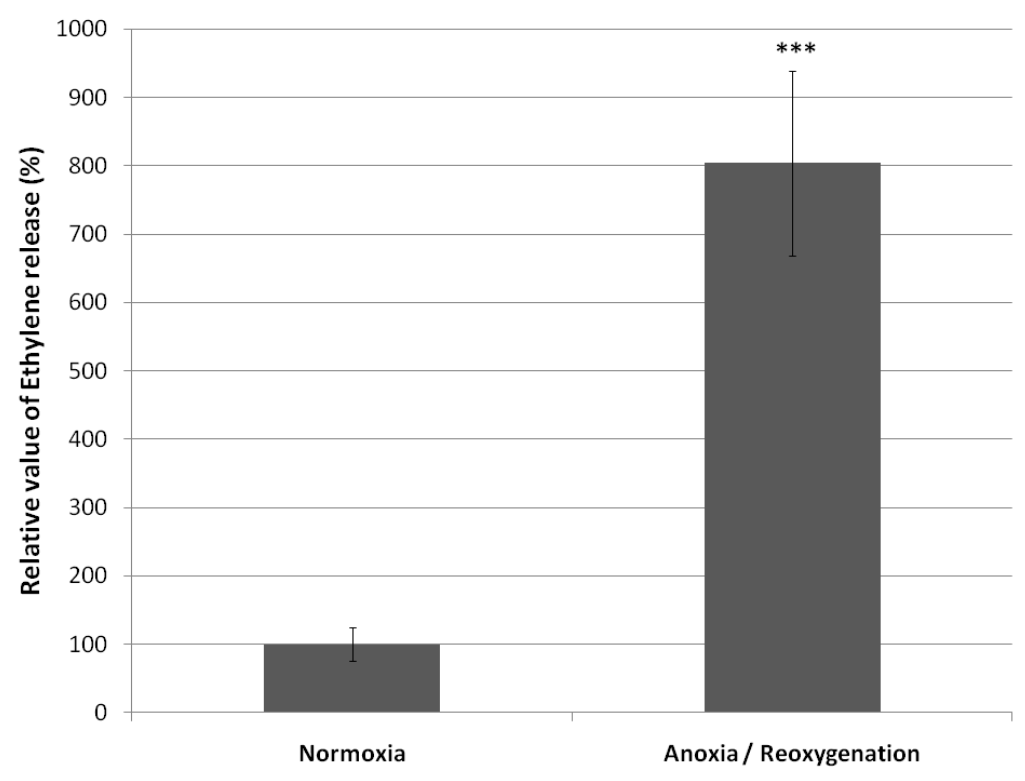

Fig. (4). Relative value (mean $\pm \mathrm{SD}$ ) of ethylene generated by the oxidation of $\alpha$-keto- $\gamma$-(methylthio)butyric acid (KMB) by the ROS produced by $5.10^{6}$ equine endothelial cells submitted to 1 hour anoxia followed by reoxygenation $(\mathrm{n}=6)$. The ethylene value produced by the control cells (normoxia) is taken as $100 \%$.

$* * * P<0.001$ versus Normoxia.

ethylene originating from the degradation of KMB by free radicals. The reaction was amplified by horseradish peroxidase (HRP), which reacts preferentially with $\mathrm{H}_{2} \mathrm{O}_{2}$, itself resulting from the dismutation of superoxide anion [24]. Upon anoxia/reoxygenation, we found by GC an important ethylene production compared to the control, confirming the superoxide anion production in our $\mathrm{A} / \mathrm{R}$ model of equine endothelial cells.

To explain the origin of $\mathrm{O}_{2}^{-}$in the cellular compartment we cannot exclude other sources than mitochondria as described in previous studies on human endothelial cells submitted to $\mathrm{A} / \mathrm{R}[14,31]$. To investigate on both cellular and mitochondrial compartments we designed two models of $\mathrm{A} / \mathrm{R}$ using two spin trap agents. Because of the short half-life of superoxide anion and the water-soluble nature of DMPO [32], the latter one was used to investigate the ROS produced after the burst at the cellular level while the acyclic nitrone POBN was used to assess in depth within mitochondria. Indeed, the studies performed by the previous authors using DMPO could not measure adequately the production of ROS from mitochondria. The lipophilic and water-soluble nitrone POBN can cross the membrane and reach all the cell compartments including the mitochondrial matrix. The ESR spectra observed with POBN were similar to those detected with isolated mitochondria and alveolar cells, and due to a mitochondrial dysfunction at the level of the electron transport chain $[27,30]$. When superoxide anion is produced in the mitochondria, it can react with the haemic iron of the respiratory chain enzymes. So, superoxide anion was able to attack the mitochondrial enzyme aconitase, and to release the labile iron from the cluster $[4 \mathrm{Fe}-4 \mathrm{~S}]^{2+}[33]$. Consequently, the simultaneous presence of free iron and $\mathrm{H}_{2} \mathrm{O}_{2}$ (coming from the dismutation of the superoxide anion) may produce ferryl ions which release the highly reactive hydroxyl radical, responsible for lipid peroxidation, particularly deleterious for the mitochondrial cardiolipins and the stability of the cytochrome c-cardiolipin complexes [34].

The gas chromatography results confirmed that the ROS production by endothelial cells was not a transient phenomenon, but continued after reoxygenation. Without excluding a role of xanthine oxidase, we thus hypothesized that the production of ROS starting at and continuing after re-oxygenation resulted from the alterations of the cellular respiratory function in mitochondria.

We are particularly interested by the interactions of endothelium cells with neutrophils in equine laminitis, a pathology which has been proposed to be linked to ischemiareperfusion phenomenon. In laminitis, the ability of primed neutrophils to produce ROS [35], and the activation of endothelial cells have been proven [36]. In our GC study, HRP was used as enhancer of the observed pro-oxidant signal, mimicking the role of a neutrophil peroxidase, myeloperoxidase, in the in vivo ischemia-reperfusion conditions. ROS also promote endothelial cell and neutrophil expression of membrane adhesion molecule [37, 38], what can explain the massive afflux of neutrophils after reperfusion [6]. Myeloperoxidase from the primary granules of neutrophils may intervene and use superoxide anionderived $\mathrm{H}_{2} \mathrm{O}_{2}$ to increase oxidative injuries, an hypothesis further supported by the observation that equine endothelial cells uptake MPO [23], and that vessel immobilized MPO is removed by enoxaparin restoring the availability of $\mathrm{NO}$ and the vasodilator function of endothelium [39].

\section{CONCLUSION}

High resolution oxygraphy allowed to monitor and control accurately in real time cellular anoxia periods, and demonstrated an alteration of the oxygen consumption by anoxia. Taken together, ESR and GC techniques successfully demonstrated that endothelial cells are able to produce ROS 
during anoxia and re-oxygenation. These findings thus raise the question of the possible role of endothelial ROS on neutrophil infiltration and deleterious interactions between endothelium and neutrophils in pathologies linked to ischemia-reperfusion phenomenon. The effect of myeloperoxidase and activated neutrophils on equine endothelial cells submitted to $\mathrm{A} / \mathrm{R}$ still remains a matter of interest and will be investigated in future.

\section{CONFLICT OF INTEREST}

Non declared.

\section{ACKNOWLEDGEMENTS}

This work was supported by a FNRS (National Fund for Scientific Research, Belgium) grant. G. de la Rebière de Pouyade was recipient of a FRIA (Fund for the Research in Industry and Agriculture) scholarship. Authors would like to thank Ariane Niesten for her technical assistance.

\section{REFERENCES}

[1] Rubanyi, G.M. The role of endothelium in cardiovascular homeostasis and diseases. J. Cardiovasc. Pharm., 1993, 22, S1-14.

[2] Nomura, M.; Yamagishi, S.; Harada, S.; Hayashi, Y.; Yamashima, T.; Yamashita, J.; Yamamoto, H. Possible participation of autocrine and paracrine vascular endothelial growth factors in hypoxia-induced proliferation of endothelial cells and pericytes. $J$. Biol. Chem., 1995, 270, 28316-28324.

[3] Duffy, T.C.; Kirby, R.; Rudloff, E. Critical role of the vascular endothelial cell in health and disease: a review article. J. Vet. Emerg. Crit. Car., 2004, 14, 84-99.

[4] Kokura, S.; Yoshida, N.; Yoshikawa, T. Anoxia/reoxygenationinduced leukocyte-endothelial cell interactions. Free Radic. Biol. Med., 2002, 33, 427-432.

[5] Matsuda, N.; Hattori, I. Vascular biology in sepsis: pathophysiological and therapeutic significance of vascular dysfunction. J. Smooth Muscle Res., 2007, 43, 117-137.

[6] Arndt, H.; Kubes, P.; Granger, D.N. Involvement of neutrophils in ischemia-reperfusion injury in the small intestine. Klin. Wochenschr. 1991, 69, 1056-1060.

[7] Bzeizi, K.I.; Jalan, R.; MacGregor, I.; Drummond, O.; Lee, A.; Hayes, P.C. Neutrophil elastase: a determinant of endothelial damage and reperfusion injury after liver transplantation? Transplantation, 1996, 62, 916-920.

[8] Deby-Dupont, G.; Deby, C.; Lamy, M. Neutrophil myeloperoxidase revisited: it's role in health and disease. Intensivmed, 1999, 36, 500-513.

[9] Benbarek, H.; Grulke, S.; Deby-Dupont, G.; Deby, C.; MathyHartert, M.; Caudron, I.; Dessy-Doize, C.; Lamy, M.; Serteyn, D. Cytotoxicity of stimulated equine neutrophils on equine endothelial cells in culture. Equine Vet. J., 2000, 32, 327-333.

[10] Eiserich, J.P.; Baldus, S.; Brennan, M.L.; Ma, W.X.; Zhang, C.X.; Tousson, A.; Castro, L.; Lusis, A.J.; Nauseef, W.M.; White, C.R.; Freeman, B.A. Myeloperoxidase, a leukocyte-derived vascular NO oxidase. Science, 2002, 296, 2391-2394.

[11] Harada, N.; Okajima, K.; Isobe, H. Role of neutrophil elastase in development of pulmonary vascular injury and septic shock in rats. Shock, 2008, 30, 379-387.

[12] Duilio, C.; Ambrosio, G.; Kuppusamy, P.; DiPaula, A.; Becker, L.C.; Zweier, J.L. Neutrophils are primary source of O2 radicals during reperfusion after prolonged myocardial ischemia. Am. J. Physiol. Heart Circ. Physiol., 2001, 280, H2649-H2657.

[13] Zweier, J.L.; Duke, S.S.; Kuppusamy, P.; Sylvester, J.T.; Gabrielson, E.W. Electron paramagnetic resonance evidence that cellular oxygen toxicity is caused by the generation of superoxide and hydroxyl free radicals. FEBS Lett. , 1989, 252, 12-26.

[14] Zweier, J.L.; Broderick, R.; Kuppusamy, P.; Thompson-Gorman, S.; Lutty, G.A. Determination of the mechanism of free radical generation in human aortic endothelial cells exposed to anoxia and reoxygenation. J. Biol. Chem., 1994, 269, 24156-24162.

[15] Ray, R.; Shah, A.M. NADPH oxidase and endothelial cell function. Clin. Sci. (Lond), 2005, 109, 217-226.
[16] Duchen, M.R. Mitochondria in health and disease: perspectives on a new mitochondrial biology. Mol. Aspects Med., 2004, 25, 365451.

[17] De Vriese, A.S.; Verbeuren, T.J.; Van de Voorde, J.; Lameire, N.H.; Vanhoutte, P.M. Endothelial dysfunction in diabetes. Brit. J. Pharmacol., 2000, 130, 963-974.

[18] Simonini, G.; Pignone, A.; Generini, S.; Falcini, F.; Cerinic, M.M. Emerging potentials for an antioxidant therapy as a new approach to the treatment of systemic sclerosis. Toxicology, 2000, 155, 1-15.

[19] Verma, S.; Maitland, A.; Weisel, R.D.; Li, S.H.; Fedak, P.W.M.; Pomroy, N.C.; Mickle, D.A.G.; Li, R.K.; Ko, L.; Rao, V. Hyperglycemia exaggerates ischemia-reperfusion-induced cardiomyocyte injury: Reversal with endothelin antagonism. $J$. Thorac. Cardiovasc. Surg., 2002, 123, 1120-1124.

[20] Settergren, M.; Bohm, F.; Malmstrom, R.E.; Channon, K.M.; Pernow, J. 1-Arginine and tetrahydrobiopterin protects against ischemia/reperfusion-induced endothelial dysfunction in patients with type 2 diabetes mellitus and coronary artery disease. Atherosclerosis, 2009, 204, 73-78.

[21] Hood, D.M.; Grosenbaugh, D.A.; Mostafa, M.B.; Morgan, S.J.; Thomas, B.C. The Role of vascular mechanisms in the development of acute equine laminitis. J. Vet. Intern. Med., 1993, 7, 228-234.

[22] Moore, R.M.; Muir, W.W.; Granger, D.N. Mechanisms of gastrointestinal ischemia-reperfusion injury and potential therapeutic interventions: a review and its implications in the horse. J. Vet. Intern. Med., 1995, 9, 115-132.

[23] de la Rebiere, G.; Franck, T.; Deby-Dupont, G.; Salciccia, A.; Grulke, S.; Peters, F.; Serteyn, D. Effects of unfractionated and fractionated heparins on myeloperoxidase activity and interactions with endothelial cells: possible effects on the pathophysiology of equine laminitis. Vet. J., 2008, 178, 62-69.

[24] Deby-Dupont, G.; Mouithys-Mickalad, A.; Serteyn, D.; Lamy, M.; Deby, C. Resveratrol and curcumin reduce the respiratory burst of Chlamydia-primed THP-1 cells. Biochem. Biophys. Res. Commun., 2005, 333, 21-27.

[25] Saikumar, P.; Dong, Z.; Weinberg, J.M.; Venkatachalam, M.A Mechanisms of cell death in hypoxia/reoxygenation injury. Oncogene, 1998, 17, 3341-3349.

[26] Simon, H.U.; Haj-Yehia, A.; Levi-Schaffer, F. Role of reactive oxygen species (ROS) in apoptosis induction. Apoptosis, 2000, 5 , 415-418.

[27] Mouithys-Mickalad, A.; Mathy-Hartert, M.; Du, G.; Sluse, F.; Deby, C.; Lamy, M.; Deby-Dupont, G. Oxygen consumption and electron spin resonance studies of free radical production by alveolar cells exposed to anoxia: inhibiting effects of the antibiotic ceftazidime. Redox Rep., 2002, 7, 85-94.

[28] Gueler, F.; Gwinner, W.; Schwarz, A.; Haller, H. Long-term effects of acute ischemia and reperfusion injury. Kidney Int., 2004, 66, 523-527.

[29] Schneider, N.; Mouithys-Mickalad, A.L.; Lejeune, J.P.; DebyDupont, G.P.; Hoebeke, M.; Serteyn, D.A. Synoviocytes, not chondrocytes, release free radicals after cycles of anoxia/reoxygenation. Biochem. Biophys. Res. Commun., 2005, 334, 669673.

[30] Du, G.; Mouithys-Mickalad, A.; Sluse, F.E. Generation of superoxide anion by mitochondria and impairment of their functions during anoxia and reoxygenation in vitro. Free Radic. Biol. Med., 1998, 25, 1066-1074.

[31] Arroyo, C.M.; Carmichael, A.J.; Bouscarel, B.; Liang, J.H.; Weglicki, W.B. Endothelial cells as a source of oxygen-free radicals. An ESR study. Free Radic. Res. Commun., 1990, 9, 287296.

[32] Berliner, L.J.; Khramtsov, V.; Fujii, H.; Clanton, T.L. Unique in vivo applications of spin traps. Free Radic. Biol. Med., 2001, 30, 489-499.

[33] Vasquez-Vivar, J.; Kalyanaraman, B.; Kennedy, M.C. Mitochondrial aconitase is a source of hydroxyl radical. An electron spin resonance investigation. J. Biol. Chem., 2000, 275, 14064-14069.

[34] Fariss, M.W.; Chan, C.B.; Patel, M.; Van Houten, B.; Orrenius, S. Role of mitochondria in toxic oxidative stress. Mol. Interv., 2005 , 5, 94-111.

[35] Hurley, D.J.; Parks, R.J.; Reber, A.J.; Donovan, D.C.; Okinaga, T.; Vandenplas, M.L.; Peroni, J.F.; Moore, J.N. Dynamic changes in circulating leukocytes during the induction of equine laminitis with 
black walnut extract. Vet. Immunol. Immunopathol., 2006, 110, 195-206.

[36] Katwa, L.C.; Johnson, P.J.; Ganjam, V.K.; Kreeger, J.M.; Messer, N.T. Expression of endothelin in equine laminitis. Equine Vet. J., 1999, 31, 243-247.

[37] Fraticelli, A.; Serrano, C.V.; Bochner, Jr B.S.; Capogrossi, M.C.; Zweier, J.L. Hydrogen peroxide and superoxide modulate leukocyte adhesion molecule expression and leukocyte endothelial adhesion. Biochim. Biophys. Acta, 1996, 1310, 251-259.
[38] Ichikawa, H.; Kokura, S.; Aw, T.Y. Role of endothelial mitochondria in oxidant production and modulation of neutrophil adherence. J. Vasc. Res., 2004, 41, 432-444.

[39] Rudolph, T.K.; Rudolph, V.; Witte, A.; Klinke, A.; Szoecs, K.; Lau, D.; Heitzer, T.; Meinertz, T.; Baldus, S. Liberation of vessel adherent myeloperoxidase by enoxaparin improves endothelial function. Int. J. Cardiol., 2010, 140, 42-47.

Received: August 28, 2011

() de la Rebière de Pouyade et al.; Licensee Bentham Open.

This is an open access article licensed under the terms of the Creative Commons Attribution Non-Commercial License (http://creativecommons.org/licenses/by-nc/3.0/) which permits unrestricted, non-commercial use, distribution and reproduction in any medium, provided the work is properly cited. 